Pengaruh Persepsi Siswa Tentang Kompetensi Guru Terhadap Hasil Belajar ..., Volume 7 No 1 Tahun 2019

\title{
PENGARUH PERSEPSI SISWA TENTANG KOMPETENSI GURU TERHADAP HASIL BELAJAR SISWA KELAS XI PADA MATA PELAJARAN EKONOMI DI SMA NEGERI 15 SURABAYA TAHUN AJARAN 2018/2019
}

\author{
Bagus Prayogo \\ Program Studi Pendidikan Ekonomi, Fakultas Ekonomi, Universitas Surabaya, email: \\ bagusprayogo1@mhs.unesa.ac.id
}

\begin{abstract}
Abstrak
Tujuan yang diharapkan dalam studi ini ialah mengetahui pengaruh langsung positif kompetensi guru terhadap hasil belajar siswa kelas XI pada mata pelajaran ekonomi di SMA Negeri 15 Surabaya tahun ajaran 2018/2019. Metode studi yang digunakan ialah asosiatif kausal dengan melakukan pendekatan kuantitatif. Populasi pada studi ini ialah semua siswa kelas XI SMA Negeri 15 Surabaya yang mempelajari ekonomi sejumlah 251 siswa. Berdasarkan hasil random sampling, sampel studi ini ialah siswa kelas XI MIPA 2 SMA Negeri 15 Surabaya sejumlah 35 siswa. Teknik pengumpulan data pada studi ini memanfaatkan angket untuk mengetahui persepsi siswa tentang kompetensi guru dan nilai PTS untuk mengetahui hasil belajar. Berlandaskan hasil uji t (Parsial) studi ini memperlihatkan bahwa persepsi siswa tentang kompetensi guru berpengaruh positif dan signifikan terhadap hasil belajar siswa.

Kata kunci : Persepsi Siswa Tentang Kompetensi Guru, Hasil Belajar
\end{abstract}

Abstract

The expected goal in this study is to know the positive direct effect of teacher competence on the learning outcomes of class XI students on economic subjects in Surabaya 15 High School in the academic year 2018/2019. The research method used is associative causal by carrying out a quantitative approach. The population in this study were all students of class XI Surabaya 15 High School who studied the economy of 251 students. Based on the results of random sampling, the sample of this study was students of class XI MIPA 2 Surabaya 15 High School numbering 35 students. Data collection techniques in this study used a questionnaire to determine students' perceptions of teacher competence and PTS scores to find out the learning outcomes. Based on the results of the $t$ test (Partial) this study shows that students' perceptions of teacher competence have a positive and significant effect on student learning outcomes.

Keywords: Student Perception About Teacher Competence, Learning Outcomes

\section{PENDAHULUAN}

Pendidikan dikatakan berhasil apabila pengetahuan akademik maupun non akademik siswa dapat berkembang. Untuk mengembangkan pengetahuan siswa tersebut, maka muncul peran guru yang bisa dikatakan sebagai fasilitator pengembangan diri siswa. Seorang guru dituntut harus bisa mengetahui apa dan bagaimana cara mengembangkan pengetahuan seorang siswa. Untuk mengetahui keberhasilan guru, maka perlu adanya penilaian dari siswa karena sejatinya mereka merupakan gambaran utama dari keberhasilan suatu pendidikan.

Pendidikan merupakan wadah dalam membentuk bangsa Indonesia yang bermartabat melalui peningkatan mutu SDM. Pendidikan ialah seperangkat kegiatan aktivitas belajar mengajar yang terencana dengan tujuan agar peserta didik mengembangkan potensi dirinya. Adanya pendidikan merupakan salah satu upaya dalam rangka mencapai salah satu harapan negara Indonesia yang tercantum pada Pembukaan UUD 1945 yakni, mencerdaskan kehidupan bangsa. Wujud nyata berjalannya pendidikan adalah melalui kegiatan pembelajaran yang selama ini berlangsung di sekolah. Dalam melaksanakan kegiatan pembelajaran diperlukan seseorang yang merencanakan dan mengatur kegiatan pembelajaran sesuai dengan pedoman dalam perangkat pembelajaran yang telah dibuat demi terselenggaranya aktivitas belajar mengajar. Orang yang mengatur terselenggaranya kegiatan pembelajaran inilah yang disebut sebagai guru.

Kompetensi merupakan syarat yang harus dimiliki oleh setiap tenaga pendidik, apabila seorang guru tidak cukup berkompeten, maka hal ini menjadi hambatan dalam keberlangsungan kegiatan belajar mengajar 
Pemerintah melalui PP Nomor 74 Tahun 2008 menyatakan kompetensi pedagogik, kepribadian, sosial dan profesional harus dikuasai oleh tenaga pendidik. Setiap kompetensi tersebut haruslah dimiliki seorang guru demi terwujudnya tujuan pembelajaran yang akan dicapai.

Dalam mencapai suatu hasil belajar yang maksimal oleh siswa maka diperlukan suatu kegiatan oleh seorang individu yang secara sadar untuk mempelajari berbagai macam ilmu pengetahuan dari berbagai sumber yang ada di lingkungan sekitarnya, kegiatan yang dimaksud ini adalah belajar.

Belajar diperlukan individu untuk memperoleh dan menambah ilmu pengetahuan dan keterampilan untuk meningkatkan hasil belajarnya. Belajar bisa dikatakan pasti dilakukan oleh semua orang. Belajar juga bisa dilakukan dimana saja, sekolah, kampus, warung kopi, bahkan di jalan pun kita bisa belajar. Di lingkungan sekolah, hasil belajar siswa bisa diukur dengan adanya tugas, Ujian Tengah Semester (PTS), maupun Penilaian Akhir Tahun (PAT). Dikatakan siswa tersebut bisa lulus apabila dari hasil tes tersebut telah memenuhi KKM.

Dalam melaksanakan kegiatan belajar mengajar di sekolah, para pendidik mengacu pada kurikulum 2013. Pada pelaksanaan kegiatan pembelajaran dengan menggunakan kurikulum 2013, pendekatan pembelajaran lebih berpusat kepada siswa. Pada kurikulum 2013 siswa diharuskan lebih aktif untuk membangun pengetahuannya secara mandiri dan mengembangkan keterampilannya. Keadaan ini merupakan tantangan baru untuk tenaga pendidik Indonesia. Pasalnya kegiatan pembelajaran saat ini tidak hanya sebagai wadah untuk guru menyampaikan materi dan siswa secara pasif menerima materi maupun memberi umpan balik, namun guru menjadi fasilitator yang menyediakan kegiatan pembelajaran untuk siswa lebih aktif pada kegiatan pembelajaran. Dalam hal ini kualitas kompetensi guru yang dimiliki seorang guru akan menentukan bagaimana seorang guru dapat mengelolah kelasnya dan menjadi fasilitator yang profesional untuk mengarahkan siswanya mengkonsep ilmu pengetahuan dan mengembangkan keterampilannya secara mandiri dan membuat kegiatan pembelajaran menjadi aktif dan sesuai tujuan pembelajaran yang dicapai.

Fattah (2000) menyatakan ilmu ekonomi ialah ilmu untuk menganalisis aktivitas dan transformasi yang terjadi pada ekonomi, seperti kecenderungan (trend) dalam harga, hasil produksi, pengangguran dan ekspor impor. Ketika tanda-tanda tersebut berhasil di analisis, maka dapat dimanfaatkan oleh pemangku kebijakan untuk mengeluarkan strategi ekonomi yang tepat dalam upaya transparansi ekonomi bangsa.

Saat ini Indonesia telah mengikuti Masyarakat Ekonomi ASEAN atau lebih populer dengan sebutan MEA. Untuk menghadapi MEA, masyarakat Indonesia dituntut untuk memiliki kompetensi yang memadai agar mampu bersaing dengan negara ASEAN yang lainnya. Pada tahun 2016, Charisniadji mengatakan pemenuhan SDM untuk menuju MEA harus disegerakan lantaran kompetensi SDM Indonesia sampai hari ini belum bisa dikatakan cukup. Dari sudut pandang mutu pendidikan, misalnya, Indonesia berada di pada tingkat bawah dunia. Sedangkan mutu guru menjadi faktor penting penunjang mutu pendidikan. Pengamat pendidikan Charisniadji (dalam Anonim,2016) mengatakan bahwa dari Uji Kompetensi Guru (UKG) ada 192 dari 1,6 juta guru yang mendapatkan poin di atas 90 , sementara poin rerata UKG 56 belaka. Bukan angka yang bagus, ketika kita dihadapkan pada tuntutan persaingan SDM yang begitu ketat, tetapi kualitas guru di Indonesia hanya memiliki rata-rata UKG 56.

SMA Negeri 15 Surabaya ialah satu dari sekian sekolah favorit yang hadir di ibukota provinsi Jawa Timur. Banyak lulusan SMP yang ingin menjadi siswa di SMA Negeri 15 Surabaya, baik dari dalam kota maupun luar kota. Dari sekian banyak pendaftar, hanya 431 siswa yang diterima di SMA Negeri 15 Surabaya. Tingkat pendidikan guru di SMA tersebut juga terbilang tinggi. Seperti pada mata pelajaran ekonomi, bapak Herman Hardiyanto merupakan lulusan S2 di Universitas Negeri Surabaya.

Dari hasil studi pendahuluan tanggal 22 Mei 2017, sebanyak 251 siswa mengikuti PTS (Penilaian Tengah Semester). Dari 251 siswa yang mengikuti PTS, 61 diantaranya tidak memenuhi KKM. Itu berarti, 24\% siswanya masih mengikuti kegiatan remedial. Sebuah angka yang bagus untuk ukuran sekolah favorit di kota besar seperti Surabaya, mengingat nilai KKM yang ditentukan oleh SMA Negeri 15 Surabaya yang tinggi, yaitu 80. Pada keseluruhan kelas XI MIPA yang mempelajari ekonomi, tingkat remedial sebesar 20\%. Dengan tingkat remedial XI MIPA tertinggi pada kelas XI MIPA 1 (25\%) dan tingkat remedial terendah pada kelas XI MIPA 2,XI MIPA 4 dan XI MIPA 5 (17\%). Sedangkan pada keseluruhan kelas XI IPS, tingkat remedial sebesar 36. Dengan tingkat remedial tertinggi pada kelas XI IPS 1 (42\%) dan tingkat remedial terendah pada kelas XI IPS 2 (31\%).

Hamalik (2006) menyatakan hubungan kompetensi guru terhadap aktivitas dan hasil belajar peserta didik adalah hal yang tidak bisa 
dipisahkan. Proses pembelajaran dan hasil belajar peserta didik tidak hanya sekolah, pola pendidikan, struktur dan misi kurikulum yang menentukan, tetapi mayoritas kompetensi tenaga pendidik yang menjadi penentu. Tenaga pendidik dengan kompetensi mumpuni lebih mampu mengorganisir kelasnya, sehingga proses pembelajaran berada pada tingkat optimal.

Studi Inayah dkk (2011) menghasilkan kesimpulan dimana terdapat jalur signifikan yang menghubungkan variabel kompetensi guru terhadap hasil belajar mata pelajaran ekonomi (sig = $0,000<0,05)$ sehingga bukan alasan untuk menghilangkan jalur tersebut, serta diperoleh dampak lagsung positif kompetensi guru terhadap hasil belajar ekonomi, yaitu sebesar 0,409 atau $40,9 \%$.

Dari pemaparan diatas maka peneliti akan melakukan studi dengan judul "Pengaruh Persepsi Siswa Tentang Kompetensi Guru Terhadap Hasil Belajar Siswa Kelas XI Pada Mata Pelajaran Ekonomi Di SMA Negeri 15 Surabaya".

Rumusan Masalah pada studi ini adalah bagaimana pengaruh persepsi siswa tentang kompetensi guru terhadap hasil belajar siswa kelas XI pada mata pelajaran ekonomi di SMA Negeri 15 Surabaya tahun ajaran 2018/2019?

Tujuan yang diharapkan pada studi ini adalah untuk melihat dampak persepsi siswa tentang kompetensi guru terhadap hasil belajar siswa kelas XI pada mata pelajaran ekonomi di SMA Negeri 15 Surabaya tahun ajaran 2018/2019.

\section{KAJIAN TEORITIS \\ Persepsi}

Jalaludin (1998) memberikan pernyataan bahwasanya persepsi adalah pengetahuan individu terhadap suatu objek, atau peristiwa yang kemudian disimpulkan oleh individu tersebut. Sederhananya persepsi adalah pengalaman tentang peristiwa yang ada di sekitar individu untuk kemudian diorganisasikan dan ditafsirkan.

\section{Kompetensi Guru}

Usman (2005) menyatakan kompetensi guru adalah kecakapan dan otoritas yang dimiliki oleh tenaga pendidik dalam rangka menjalankan tugas keguruannya. Kompetensi guru dapat diartikan kemampuan terkait pemahaman, kelihaian dan tingkah laku yang harus dimiliki, dijiwai dan dikuasai oleh guru untuk melaksanakan kewenangan dan melaksanakan profesi keguruan.

\section{Hasil Belajar}

Kunandar (2013) menyatakan hasil belajar ialah pencapaian peserta didik dalam hal kognitif, afektif, maupun psikomotor pasca proses pembelajaran. Hasil belajar dapat diartikan seluruh kemampuan atau hasil yang diperoleh dalam proses pembelajaran di sekolah yang ditentukan berdasarkan nilai tes.

\section{METODE}

Jenis studi kuantitatif dipilih pada studi ini dikarenakan banyak memanfaatkan nominal, mulai dari proses pemberkasan informasi, pengolahan informasi, sampai hasil dari studinya (Arikunto, 2006).

Rancangan studi yang dipakai merupakan rancangan studi asosiatif kausal karena menelaah interaksi antara satu variabel terhadap variabel lainnya (Umar, 2008).

Populasi dari studi berikut ialah semua peserta didik kelas XI SMA Negeri 15 Surabaya yang mempelajari ekonomi sejumlah 251 siswa. Pemilihan sampel dari studi berikut dengan memanfaatkan metode Cluster Sampling (Area Sampling) yang kemudian didapatkan kelas XI MIPA 2 sejumlah 35 siswa sebagai sampel dalam studi ini.

Dua teknik pemberkasan informasi yang akan diterapkan dalam studi berikut yaitu:

1. Angket atau kuesioner

Kuesioner ialah kumpulan persoalan yang dipakai untuk mendapatkan informasi dari informan(Arikunto, 2006).

Angket atau kuesioner pada studi berikut dimanfaatkan untuk mengerti lebih lanjut bagaimana persepsi siswa tentang kompetensi guru.

2. Dokumentasi

Teknik dokumentasi dimanfaatkan untuk mengetahui benda-benda tertulis seperti arsip, anggaran dasar, bacaan, dan sebagainya (Arikunto, 2006).

Teknik telaah informasi yang digunakan pada studi berikut adalah regresi linier sederhana karena berlandaskan pada hubungan sebuah variabel independen dengan satu variabel dependen baik secara fungsional maupun kausal (Sugiyono, 2012).

Rumus regresi linier sederhana sebagai berikut: 
$\hat{Y}=a+b x$

Dimana :

$\hat{Y}=$ materi dalam variabel dependen yang diprediksikan.

$\mathrm{a}=$ nilai $Y$ ketika nilai $\mathrm{X}=0$ (nilai konstan)

$\mathrm{b}=$ Angka arah atau koefisien, yang menunjukan angka penurunan maupun peningkatan variabel dependen yang berlandaskan pada perubahan variabel independen. Bila $(-)$ maka arah garis turun, dan bila $(+)$ arah garis naik.

$X=$ materi pada variabel independen yang memiliki nilai tertentu

\section{HASIL PENELITIAN DAN PEMBAHASAN}

Dari tabel output SPSS 25 dapat disimpilkan bahwa hubungan antara variabel bebas persepsi siswa tentang kompetensi guru $(X)$ dengan variabel terikat hasil belajar $(\mathrm{Y})$ adalah :

$\hat{Y}=a+b x$

$\hat{Y}=48,737+0,412$

Model regresi linier sederhana tersebut dapat dijelaskan sebagai berikut :

1) Nilai a atau konstanta sebesar 48,737 menjelaskan variabel dependen tanpa dipengaruhi oleh variabel independent. Ini menunjukkan jika persepsi siswa tentang kompetensi guru berada pada nilai nol, hasil belajar siswa bernilai 48,737.

2) Nilai bx atau koefisien persamaan diatas menjelaskan angka koefisien persepsi siswa tentang kompetensi guru adalah 0,412. Dapat diartikan jika persepsi siswa tentang kompetensi guru meningkat satu point, maka hasil belajar siswa mengalami peningkatan 0,412 point.

Berdasarkan tabel output coefficients diatas, diketahui bahwa nilai koefisien regresi variabel persepsi siswa tentang kompetensi guru $(X)$ adalah 0,412 dan bernilai positif. Bisa disimpulkan jika persepsi siswa tentang kompetensi guru (X) memiliki pengaruh positif terhadap hasil belajar $(\mathrm{Y})$, peningkatan variabel $X$ akan diikuti peningkatan variabel Y.

Dari tabel itu juga bisa dilihat nilai signifikansi 0,016 lebih kecil dari 0,05. dapat ditarik kesimpulan jika variabel $X$ berpengaruh signifikan terhadap variabel Y.

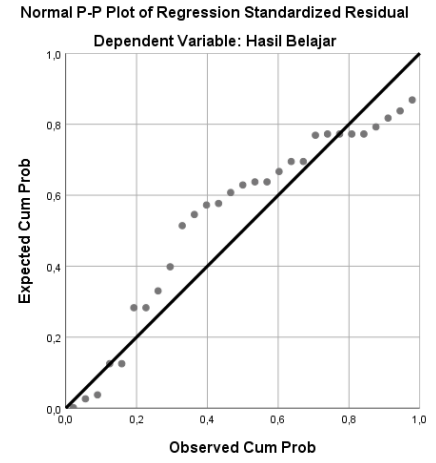

\section{Gambar 1 Grafik Probality Plot Normalitas}

Grafik tersebut menunjukkan bahwa informasi yang didapatkan peneliti berdistribusi normal. Hal itu bisa dilihat dari persebaran titik-titik yang berada di sekitar garis diagonal dan mengikutinya.

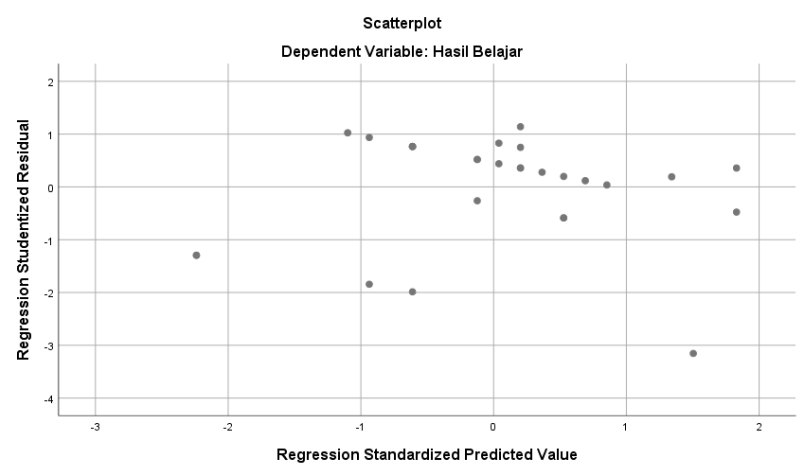

Gambar 2 Grafik Scartter Plot

Grafik tersebut menunjukkan jika model regresi ini tidak terjadi heterokedastisitas. Hal itu bisa diketahui dari persebaran titik-titik informasi yang berada di atas dan di bawah titik nol sumbu vertikal serta tidak membentuk suatu pola tertentu.

Tabel 1 Hasil Uji Linieritas

\begin{tabular}{|c|c|c|c|c|c|c|c|}
\hline \multicolumn{8}{|c|}{ ANOVA Table } \\
\hline & & & $\begin{array}{l}\text { Sum of } \\
\text { Squares }\end{array}$ & Df & $\begin{array}{c}\text { Mean } \\
\text { Square }\end{array}$ & $\mathrm{F}$ & Sig. \\
\hline $\begin{array}{c}\text { Hasil } \\
\text { Belajar * }\end{array}$ & $\begin{array}{c}\text { Betwe } \\
\text { en }\end{array}$ & $\begin{array}{c}\text { (Combin } \\
\text { ed) }\end{array}$ & 615,418 & 13 & 47,340 & 2,390 &, 055 \\
\hline Persepsi & Group & Linearity & 179,451 & 1 & 179,451 & 9,059 & ,009 \\
\hline $\begin{array}{c}\text { Siswa } \\
\text { Tentang } \\
\text { Kompete }\end{array}$ & $\mathrm{s}$ & $\begin{array}{l}\text { Deviatio } \\
\text { n from } \\
\text { Linearity }\end{array}$ & 435,967 & 12 & 36,331 & 1,834 & 133 \\
\hline nsi Guru & Withi & Groups & 297,133 & 15 & 19,809 & & \\
\hline & & otal & 912,552 & 28 & & & \\
\hline
\end{tabular}

Dari tabel tersebut dapat disimpulkan bahwa terdapat hubungan linear antara dua variabel 
studi. Hal tersebut dikarenakan nilai signifikansi pada tabel tersebut bernilai 0,133 dan lebih besar dari 0,05 .

\section{Tabel 2 Hasil Uji Koefisien Determinasi}

\begin{tabular}{rr|r|r|r} 
& & \multicolumn{2}{c}{ Model Summary } \\
Model & $\mathrm{R}$ & \multicolumn{1}{c}{$\begin{array}{c}\text { R } \\
\text { Square }\end{array}$} & $\begin{array}{c}\text { Adjusted R } \\
\text { Square }\end{array}$ & $\begin{array}{c}\text { Std. Error of the } \\
\text { Estimate }\end{array}$ \\
\hline 1 &, $443^{\mathrm{a}}$ &, 197 &, 167 & 5,21075 \\
\hline
\end{tabular}

a. Predictors: (Constant), Persepsi Siswa Tentang Kompetensi Guru

Berdasarkan tabel di atas, nilai koefisien determinasi atau $\mathrm{R}^{2}$ sebesar 0,197 yang berarti variabel X mempengaruhi variabel Y sebesar 0,197 atau $19,7 \%$, 80,3\% dipengaruhi oleh variabel lain di luar studi ini.

\section{PEMBAHASAN}

Dari hasil pengolahan informasi studi dengan program SPSS 25 didapatkan hasil studi yaitu nilai siswa kelas XI MIPA 2 tentang persepsi siswa tentang kompetensi guru berada pada rata-rata 143,93 atau 4,23 yang berada pada kriteria sangat tinggi.

Pada kompetensi pedagogik, hasil nilai angket berada pada rata-rata angka 4,1 dimana nilai tertinggi pada pernyataan Menguasai teori belajar yang mendidik dengan rata-rata nilai 4,38 dan nilai terendah pada pernyataan Menguasai karakteristik peserta didik secara individual dengan rata-rata nilai 3,76.

Pada kompetensi profesional hasil nilai angket berada pada rata-rata angka 4,26 dimana nilai tertinggi pada pernyataan Menguasai standar kompetensi mata pelajaran yang diampu dengan rata-rata 4,41 dan nilai terendah pada pernyataan Mengembangkan materi pembelajaran yang diampu secara kreatif dengan rata-rata nilai 4,1.

Pada kompetensi kepribadian hasil nilai angket berada pada rata-rata angka 4,47 dimana nilai tertinggi pada pernyataan Bertindak sesuai dengan norma agama dengan rata-rata nilai 4,76 dan nilai terendah pada pernyataan Menampilkan diri sebagai pribadi yang bisa diteladani oleh masyarakat dan Menjunjung kode etik profesi guru dengan masing-masing rata-rata nilai 4,34 .
Sedangkan pada kompetensi sosial hasil nilai angket berada pada rata-rata angka 4,13 dimana nilai tertinggi pada pernyataan Berkomunikasi secara santun dengan masyarakat dengan nilai rata-rata 4,34 dan nilai terendah pada pernyataan Bertindak obyektif dalam memperlakukan siswa dengan nilai rata-rata 3,89 .

Dari semua pernyataan pada angket persepsi siswa tentang kompetensi guru tersebut, terdapat 3 pernyataan yang memiliki nilai rata-rata di bawah 4 . Pernyataan tersebut adalah Menguasai karakteristik peserta didik secara individual, Bertindak obyektif dalam memperlakukan siswa dan Bertindak obyektif dalam memperlakukan teman sejawat.

Pada nilai hasil belajar peserta didik kelas XI MIPA 2 SMA Negeri 15 Surabaya memperoleh nilai rerata 84 dan nilai kriteria ketuntasan minimal (KKM) ialah 80, hal tersebut berarti nilai rerata hasil belajar peserta didik di atas nilai kriteria ketuntasan minimal (KKM). Dan dari hasil belajar siswa didominasi pada nilai 86 yaitu sebanyak 16 siswa dari 29 siswa. Hasil pengolahan informasi studi menggunakan SPSS 25 menunjukkan jika variabel persepsi siswa tentang kompetensi guru memberikan perubahan sebesar 0,412 kepada variabel hasil belajar.

Dari hasil rata-rata nilai angket persepsi siswa tentang kompetensi guru yang apabila diberikan skala 100, maka akan bernilai 84,66. Dan nilai rata-rata hasil PTS siswa kelas XI MIPA 2 SMA Negeri 15 Surabaya adalah 84 . Berdasarkan data tersebut, maka sesuai dengan teori dari Hamalik (2006) menyatakan hubungan kompetensi guru terhadap aktivitas dan hasil belajar peserta didik adalah hal yang tidak bisa dipisahkan. Tenaga pendidik dengan kompetensi mumpuni lebih mampu mengorganisir kelasnya, sehingga proses pembelajaran berada pada tingkat optimal.

Hasil pengolahan informasi studi juga menjelaskan peningkatan persepsi siswa tentang kompetensi guru diikuti oleh peningkatan hasil belajar peserta didik. Hal tersebut bersumber dari dari uji $\mathrm{t}$ (Parsial) yang memunculkan nilai output koefisien 0,412 bernilai positif. Hal ini sesuai dengan hasil 
studi terdahulu yang dilakukan oleh Inayah dkk (2011) dengan hasil kesimpulan terdapat pengaruh positif kompetensi guru terhadap hasil belajar siswa. Hasil olah data studi ini juga sesuai dengan studi Primaningtyas (2014).

Berdasarkan hasil pengolahan informasi studi juga dapat diketahui bahwa variabel $X$ memberikan pengaruh signifikan terhadap variabel Y. Hasil tersebut sesuai dengan studi yang dilakukan oleh Renol HS (2015), yaitu hasil belajar peserta didik dipengaruhi secara positif dan signifikan oleh tingkat kompetensi tenaga pendidik. Hasil tersebut juga sesuai dengan studi yang dilakukan oleh Hapsari dkk (2016).

\section{SIMPULAN}

Persepsi peserta didik tentang kompetensi guru terhadap hasil belajar siswa memberikan pengaruh positif. Artinya peningkatan persepsi peserta didik tentang kompetensi guru akan diikuti peningkatan hasil belajar peserta didik. Dari hasil pengolahan informasi studi juga diketahui persepsi peserta didik tentang kompentensi guru memberikan pengaruh yang signifikan terhadap hasil belajar yang diraih peserta didik.

\section{SARAN}

Dari hasil pengkajian dan analsis informasi studi, maka saran yang diberikan peneliti kepada guru mata pelajaran ekonomi SMA Negeri 15 Surabaya ialah meningkatkan penguasaan karakteristik peserta ddik, penggunaan media teknologi informasi dalam proses pembelajaran, mendukung peserta didik untuk mengembangkan potensi yang dimiliki, serta bertindak obyektif dalam memperlakukan siswa dan teman sejawat. Hal tersebut agar proses belajar mengajar yang terjadi dapat lebih maksimal.

\section{DAFTAR PUSTAKA}

Anonim, 2016, Kualitas Guru Indonesia Masih Terendah, [online],
[ (http://www.jawapos.com/read/2016/04/ 27/25739/kualitas-guru-indonesia-masihterendah, diakses tanggal 5 April 2017)

Arikunto, Suharsimi. 2006 . Prosedur Studi Suatu Pendekatan Praktik. Jakarta : Rineka Cipta.
Diasty Widar Hapsari, Arif Partono Prasetio, Drs, M.M, CPHR. Pengaruh Kompetensi Guru Terhadap Prestasi Belajar Siswa SMK Negeri 2 Bawang. e-Proceeding of Management. 4(1): 269-274

Fatah, Nanang. 2000. Ekonomi \& Pembiayaan Pendidikan. Bandung: PT Remaja Rosdakarya.

Hamalik, Oemar. (2006). Pendidikan Guru Berdasarkan Pendekatan Kompetensi. Jakarta: Bumi Aksara.

Jalaludin, Rakhmat. (1998). Psikologi Komunikasi. Bandung: Rosda.

Peraturan Pemerintah Nomor 74 tahun 2008 Tentang Guru

Primaningtyas, Ikha. 2014. Pengaruh Kompetensi Guru Dan Motivasi Belajar Siswa Terhadap Hasil Belajar Siswa Kelas VIII Pada Mata Pelajaran IPS Terpadu SMP Negeri 6 Semarang Tahun 2012/2013. Economic Education Analysis Journal. 2(2): 144-151.

Ridaul Inayah, Trisno Martono, Hery Sawiji. 2011. Pengaruh Kompetensi Guru, Motivasi Belajar Siswa, dan Fasilitas Belajar Terhadap Hasil Belajar Mata Pelajaran Ekonomi Pada Siswa Kelas XI IPS SMA Negeri 1 Lasem, Jawa Tengah Tahun Pelajaran 2011/2012. Jurnal Pendidikan Insan Mandiri. 1(1): 1-12.

Umar, Husein. 2008. Metode Studi Untuk Skripsi dan Tesis Bisnis Edisi Kedua. Jakarta: PT Raja Grafindo Persada.

Usman Uzer,M. 2005, Menjadi Guru Profesional, Bandung: Remaja Rosdakarya. 